\title{
Design, Fabrication and Performance Evaluation of a Shell and Tube Heat Exchanger for Practical Application
}

\author{
Abdulmumuni Bashiru, Adedeji Mathew Ayoade, Ologunye Opeyemi Buhari, Azeez Rasheed \\ Olatunde, and Fanifosi Johnson Olaniyi
}

\begin{abstract}
A heat exchanger is a device used to transfer thermal energy between two or more fluids, at different temperatures in thermal contact. This paper focuses on a shelland-tubes heat exchanger that involves two fluids (hot water and cold water) in contact with each other while the cold water flows through the tubes and hot water through the shell. Heat exchangers have special and practical applications in the feed water cooler in the process industries, power plants, chemical plants, refineries, process applications as well as refrigeration and air conditioning industry. The design calculations were carried out to determine the specifications of essential parameters for the development of the heat exchanger, data generated from the theoretical formulae were used to fabricate the heat exchanger using some locally available and durable materials, and the performance of the system was evaluated. Some of the parameters evaluated include heat duty, capacity ratio, effectiveness, overall heat transfer coefficient, and fouling factor. The heat exchanger was tested under various flow conditions and the results obtained were as follows; cold water inlet temperatures of $(25,25.2,25.5,25.7 \text { and } 26)^{\circ} \mathrm{C}$ increased to $(59.5,56.5,53.6,50.6$ and 47.6$){ }^{\circ} \mathrm{C}$ after $(10,8,71 / 2$, $61 / 2$, and 6 ) minutes and the hot water temperatures decreased from $(100,95,90,85 \text { and } 80)^{\circ} \mathrm{C}$ to $(66.9,65.2,63.0,61.0$, and 59.3) ${ }^{\circ} \mathrm{C}$, respectively. The design data and test data were compared in terms of the heat duty, capacity ratio, effectiveness, overall heat transfer coefficient, and fouling factor, the deviation is $2.89 \%, 0.00 \%, 2.70 \%, 26.64 \%$, and $20.00 \%$ respectively. The results obtained proved that the heat exchanger is effective, reliable and provides a good technical approach to evaluate the thermal performance of the heat exchanger and will be useful in conducting heat and mass transfer practical in thermodynamics laboratory.
\end{abstract}

Index Terms-Capacity Ratio, Effectiveness, Overall Heat Transfer Coefficient, Fouling Factor.

\section{INTRODUCTION}

Heat exchangers are devices used to facilitate the exchange of heat between two or more fluids that are at different temperatures while keeping them away from mixing [1]. These devices are built up in such a way that they do not mix or the medium of the mixture can't come in contact with each other. They are used to transfer heat between two sources where the exchange is expected to take place between process stream and power source (electric heat), process stream and utility stream (cold water, pressurized steam, etc), or two process streams resulting in the integration of energy and reduction of external heat sources [2]. The term heat exchanger applies to all equipment used to transfer heat between streams and is

Published on August 13, 2020.

Authors are with Mechanical Engineering Technology Department, Federal Polytechnic Ede, Osun State, Nigeria. commonly used in two process streams to exchange heat with each other. Consequently, the term heater or cooler is used when the exchange occurs between a process stream and a plant service stream. Exchangers can also be classified as fired (when the heat source is fuel combustion) and unfired for which the shell and tube heat exchanger (made of shell housing and smaller tubes) belong and are used in chemical-process plants. Shell and tube heat exchanger consists of series of finned tubes in which one of the fluid runs in the tube and the other fluid run over the tube (shell) to be heated or cooled during the heat exchanger operation, and high pressure, high-temperature water or steam flows at high velocity inside the tube or plate system [3]. They consist of the shell, which is a large vessel with one or more inlet and one or more outlet nozzles. Inside the shell, baffles are installed to hold the tubes together and direct the shell fluid flow to some extent [4].

Heat exchangers are normally used in a wide range of operations such as households to chemical processing, power production, chemical industries, food industries, electronics, environmental engineering, manufacturing industry, and many others [1]. They come in many types and function according to their uses, and there are no external thermal energy and work interactions. The heat transfer in the heat exchanger occurs due to conduction and convection and they are classified according to transfer processes, many fluids, and degree of surface compactness, construction features, flow arrangement, and heat transfer mechanisms [5]. The fluids used in the shell and tube heat exchanger can either be liquids or gases on either the shell or the tube side. To transfer heat efficiently, a large heat transfer area is used, leading to the use of many tubes which is an efficient way to use and avoid wastage of thermal energy.

The problems associated with shell and tube heat exchanger applications are mostly the considerable pressure drop as a result of the disturbance from the flow through the shell side area $[6,7]$. This significantly affects the cost of the heat exchangers and the presence of the multiple rows of tubes and baffles in the shell side that leads to further interference in the velocity of the liquid in the shell side region $[8,9]$. The differences in the intensity of local flow velocities also lead to the occurrence of the major heat transfer coefficients for a particular tube row.

The major factor that causes a reduction in heat exchanger performance is the effect of fouling [10]. Fouling in a heat exchanger includes any deposit of extraneous materials that appears on the heat transfer surface during the lifetime of the heat exchanger. It surfaces mostly on normal operation when the surface of the tube is covered or blocked by deposits of ash, oil, soot, dirt, and scales. Resistances to 
heat transfer are introduced while the operational capability of the heat exchanger is reduced. Mostly, the deposit is heavy enough to interfere with the fluid flow resulting in increasing pressure drop required to maintain the flow rate through the exchanger.

To improve the efficiency and performance of shell and tube heat exchanger factors such as temperature differential and flow rate are very important when designing a heat exchanger. The temperature differential is important because the coolant always needs to be at a lower temperature than the hot fluid, the flows of the fluids in both the primary and the secondary side of the heat exchanger are equally an important factor to be considered as a greater flow rate will increase the capacity of the exchanger to transfer the heat while a greater flow rate means greater mass, and thus can make it more difficult for the energy to be removed resulting to an increasing velocity and pressure loss.

The purpose of any heat exchanger is either to heat or cool the desired fluid [11] and students in tertiary institution need to know the practical application of this concept as it is required in diverse industries applications such as power generation, refrigeration, and air conditioning, cryogenics, automobiles, oil refineries and chemical processes, and other transport devices. Heat exchanger performance analysis is very important in heat and mass transfer, conservation of energy, assurance of product quality, process viability, and environmental protection, but most students find it difficult to understand the practical aspect unless demonstrated for them to appreciate the working principle. To overcome these difficulties and ensure proper learning and understanding, a shell and tube heat exchanger was fabricated to assist in carrying out practical on thermal performance analysis and heat and mass transfer in thermodynamics laboratory in universities and polytechnics.

The shell and tube heat exchanger is designed such that heat flows from a higher temperature reservoir (Shell) to the lower temperature heat reservoir (tube) and the flowing fluids provide the necessary temperature difference that forces the energy to flow between them while the temperature of hot fluid is expected to decrease while the temperature of the cold fluid will increase [12].

\section{LITERATURE REVIEW}

The heat exchanger is equipment widely used in upstream and downstream facilities and it is built for efficient heat transfer from one medium to another. Heat exchangers can be divided into a flow arrangement (parallel flow and counterflow). Parallel flow (concurrent) is a flow that occurs when two fluids enter the exchanger at the same end and travel parallel to one another to the other end while counterflow (countercurrent) is a flow that occurs when two fluids enter the exchanger from opposite ends [13].

Shell and tube heat exchanger consists of a bundle of tubes and shell on which the heat transfer occurs when one fluid that needs to be heated or cooled flows through the tubes and the second fluids runs over the tubes to provides the heat or absorbs the heat required [13]. Figure 1 below shows the interior details of the shell and tube heat exchanger.

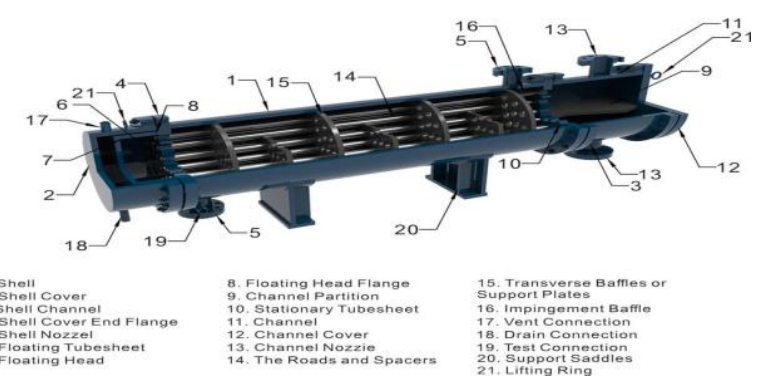

Fig. 1. The shell and tube heat exchanger interior details (Source: [13])

A lot of research has been conducted to study the flow characteristics and heat transfer in shell and tube heat exchangers.

Master, Chunangad, Boxma \& Stehlík, 2006 discovered that more than $30 \%$ of heat exchangers are made of shell and tube type. Shell and tube heat exchangers can be custom designed by considering its maintainability, flexibility, operability, and safety. This makes it very robust and enough reason to be used widely in industries [14]. For efficient heat transfer process, the heat exchanger should have a low-pressure drop, high shell side mass flow velocity, high heat transfer coefficient, and no or very low fouling and so on [15].

Durgesh \& Priyanka 2012 conducted a performance analysis on shell and tube heat exchanger and discovered that by changing the value of one variable while keeping the rest variable as constant, different results can be achieved. From the result, design of the shell and tube type heat exchanger can be optimized, the higher heat transfer rate can be achieved when the thermal conductivity of the tube metallurgy is high, the lesser the baffle spacing the more the shell side passes and the higher the heat transfer rate the lesser the pressure drop [16].

Kevin M. Lunsford 1998 evaluated the increasing heat exchanger performance through a logical series of steps as follows; to consider if the exchanger is initially operating correctly, to consider the increased pressure drop availability in the exchangers with single-phase heat transfer (lead to increased velocity resulting in higher heat transfer coefficients sufficient to improve performance), to consider the critical evaluation of the estimated fouling factors (increase the heat exchanger performance with periodic cleaning and less conservative fouling factors), and to consider how to enhance heat transfer through the use of finned tubes, inserts, twisted tubes, or modified baffles [17].

Dubey \& Verma 2014 conducted a performance analysis on shell and tube type heat exchanger under the effect of varied operating conditions and resolved that the insulation is a good tool to increase the rate of heat transfer when used properly below the level of critical thickness. The research also found that among the lagging materials cotton wool and tape always give the best heat exchanger effectiveness which depends on the value of turbulence provided. They shouldn't be a direct relation between turbulence and effectiveness while it is expected to reach its peak at some intermediate value. The result shows that the ambient condition for which the heat exchanger was tested has no significant effect on the heat exchanger performance [1].

The major gap, the fabricated shell and tube heat exchanger aimed to address when compared to the previous research is the use of local materials for fabrication and the 
exchanger is designed such that it would require less maintenance and operating cost; flexible, safe and easy to operate; economical to the imported one; and efficient in conducting heat and mass transfer practical in thermodynamics laboratory.

\section{MATERIALS AND METHODS}

\section{A. Materials and Specification}

TABLE I: MATERIAL SPECIFICATION OF THE SHELL AND TUBE HEAT EXCHANGER

\begin{tabular}{|c|c|c|c|c|}
\hline Materials & specification & qty & $\begin{array}{l}\text { rate } \\
(\mathrm{n})\end{array}$ & $\begin{array}{c}\text { amount } \\
(\mathrm{n})\end{array}$ \\
\hline angle iron & $40 \mathrm{~mm}$ by $40 \mathrm{~mm}$ & 4 & 1400 & 5,600 \\
\hline mild steel plate & $1.5 \mathrm{~mm}$ sheet & 1 & 6500 & 6500 \\
\hline galvanized sheet & $1.5 \mathrm{~mm}$ sheet & 1 & 6800 & 6800 \\
\hline lagging materials & cotton wool & - & 5500 & 5500 \\
\hline pipes and elbows & galvanized & 2 & 1600 & 3200 \\
\hline bolt and nut & $17 \mathrm{~mm}$ & 8 & 100 & 800 \\
\hline $\begin{array}{l}\text { union connector } \\
\text { and socket }\end{array}$ & - & 8 & 150 & 1200 \\
\hline flange & - & 6 & 200 & 1200 \\
\hline electrode & - & $1 \mathrm{Pac}$ & 1250 & 1250 \\
\hline rivet pin & - & $1 \mathrm{Pac}$ & 1100 & 1100 \\
\hline $\begin{array}{c}\text { brass rod for } \\
\text { brazing }\end{array}$ & & 1 & 1500 & 1500 \\
\hline copper tube & $3 / 8$ roll & 3 roll & 4100 & 12300 \\
\hline paint & 4 litres & 2 & 2200 & 4400 \\
\hline water heater & $600 w$ & 1 & 1200 & 1200 \\
\hline regulating valve & $13 \mathrm{~mm}$ diameter & 6 & 150 & 900 \\
\hline plunges & $13 a$ & 4 & 100 & 400 \\
\hline $\begin{array}{c}\text { centrifugal } \\
\text { pumping machine }\end{array}$ & $1 / 2$ horsepower & 2 & 3300 & 6600 \\
\hline $\begin{array}{l}\text { union connecting } \\
\text { pipe and pump }\end{array}$ & - & 4 & 100 & 400 \\
\hline electrical wire & $1.5 \mathrm{~mm}$ & $\begin{array}{c}7 \\
\text { yards }\end{array}$ & 100 & 700 \\
\hline tap head & - & 2 & 350 & 700 \\
\hline thermometer & - & 4 & 400 & 1600 \\
\hline socket & $15 \mathrm{a}$ & 2 & 450 & 900 \\
\hline galvanized sheet & $0.7 \mathrm{~mm}$ & 1 & 3200 & 3200 \\
\hline tire & & 4 & 250 & 1000 \\
\hline $\begin{array}{l}\text { purchase of } \\
\text { fabrication } \\
\text { materials }\end{array}$ & $\begin{array}{c}\text { cutting, welding, } \\
\text { grinding, painting \& } \\
\text { assembly }\end{array}$ & - & - & 18500 \\
\hline transportation & - & - & - & 5000 \\
\hline miscellaneous & $\begin{array}{c}\text { AutoCAD drawing, } \\
\text { typing work, and } \\
\text { others }\end{array}$ & - & - & 5000 \\
\hline total & & & & 97,450 \\
\hline
\end{tabular}

Table I above shows the fabrication cost of the shell and tube heat exchanger totaling the sum of Ninety-seven thousand four hundred and fifty Naira only (N97, 450)

\section{B. Methods}

\section{1) Design Considerations}

The main consideration for the design of the shell and tube heat exchanger includes;

1) Fluid involved

2) Corrosion potential

3) Problems of cleaning

4) Pressure drop

5) Heat transfer efficiency

The two most important methods for designing shell and tube heat exchangers are Kern's method or Bell-Delaware method. Out of the two methods above, Kern's method is the most commonly used in preliminary design and provides conservative results while the Bell-Delaware method is more accurate and can provide detailed results [15]. It can predict the heat transfer coefficient with better accuracy. In this paper, we have designed a shell and tube type heat exchanger to cool water from $100^{\circ} \mathrm{C}$ to $65^{\circ} \mathrm{C}$ using water at room temperature of $25^{\circ} \mathrm{C}$ with the application of Kern's method. The design shell and tube heat exchanger is an assembly of two inlets and outlet chambers on the shell, forty-nine (49) copper tubes with triangular pitch arrangement that allow the cooling water flow through the tube and the hot water flow from shell side in opposite direction to that of the cooling water as shown in figure 2 below;

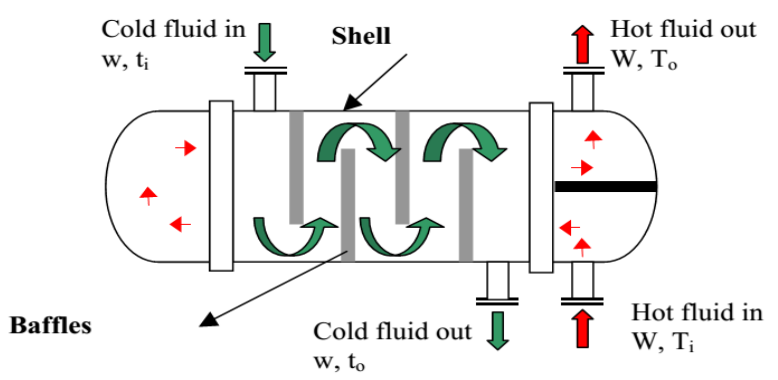

Fig. 2. Typical shell and tube heat exchanger (Source: Bureau of Energy Efficiency)

\section{2) Design Calculation}

TABLE II: SHELL AND TUBE HEAT EXCHANGER DIMENSIONS

\begin{tabular}{cccc}
\hline \hline Description & Symbol & Value & Unit \\
\hline Surface area & $A_{o}$ & 1.03900 & $\mathrm{~m}^{2}$ \\
\hline Shell outer diameter & $N_{t}$ & 49 & - \\
\hline Shell inner diameter & $D_{o}$ & 0.28200 & $\mathrm{~m}$ \\
\hline Tube outer diameter & $D_{S}$ & 0.25400 & $\mathrm{~m}$ \\
\hline Tube inner diameter & $d_{o}$ & 0.009525 & $\mathrm{~m}$ \\
\hline Tube Pitch & $d_{i}$ & 0.007525 & $\mathrm{~m}$ \\
\hline Tube sheet length & $P_{T}$ & 0.01200 & $m$ \\
\hline Baffle spacing & $L_{t s}$ & 0.02540 & $\mathrm{~m}$ \\
\hline Number of baffles & $B$ & 0.15240 & $\mathrm{~m}$ \\
\hline Baffle cut & $N_{B}$ & 4 & - \\
\hline Inner shell to baffle clearance diameter & $B_{C}$ & 0.60000 & - \\
\hline The volume of the cylinder shell & $L_{S B}$ & 0.00370 & $m$ \\
\hline The volume of the Tank & $V_{S}$ & 0.03550 & $m^{3}$ \\
\hline The diameter of the tank & $V_{T}$ & 0.03578 & $m^{3}$ \\
\hline Number of passes & $D$ & 0.38300 & $m$ \\
\hline Length of the tube & $N_{P}$ & 2 & - \\
\hline The assumed outlet temperature of the hot \\
fluid & $T_{h, o}$ & 0.7 & $m$ \\
\hline \hline
\end{tabular}

a) Mass Flow Rate from the Cold and Hot Water Tank[17]

$$
\dot{m}=\dot{Q} \times \rho_{w}
$$

b) For Cold Fluid Tank:

Height of the tank is $0.330 \mathrm{~m}$, the diameter of the tank is $0.26 \mathrm{~m}$ and diameter of the pipe is $0.013 \mathrm{~m}$ 


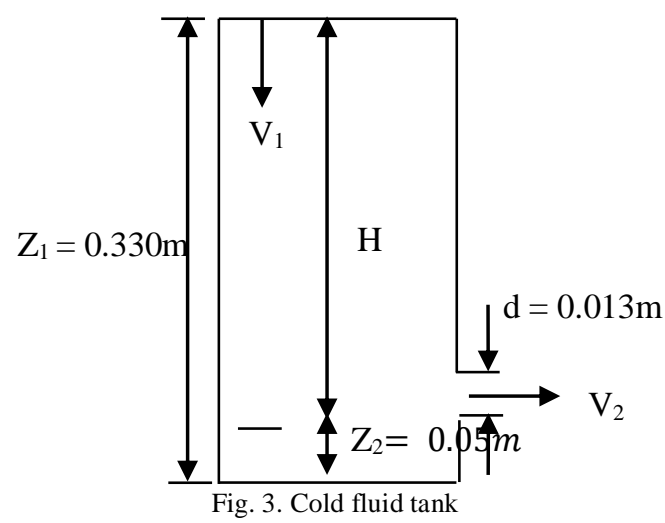

Let $Z_{1}=0.330 m, V_{1}=0, \quad Z_{2}=0.05 m$ and $d_{i}=$ $0.013 m$

$$
\begin{aligned}
& V_{c}=V_{2} \\
& H=Z_{1}-Z_{2}=0.33-0.05=0.28 m
\end{aligned}
$$

Liquid outlet velocity for cold fluid is given by

$V_{c}=C_{v} \sqrt{2 g H}$

Where the velocity coefficient of water $C_{v}=0.97$ $=0.97 \times \sqrt{2 \times 9.81 \times 0.28}=2.3 \mathrm{~m} / \mathrm{s}$

The liquid volume flow rate from the cold fluid

$\left(\dot{Q}_{c}\right)=C_{c} \frac{\pi d^{2}}{4} V_{c}$

Where the contraction coefficient for well-rounded aperture $\left(C_{c}\right)=0.97$

$$
\left(\dot{Q}_{C}\right)=0.97 \times \frac{\pi(0.013)^{2}}{4} \times 2.3=0.00030 \mathrm{~m}^{3} / \mathrm{s}
$$

This implies that; $\left(\dot{Q_{c}}\right)=0.00030 \mathrm{~m}^{3} / \mathrm{s}$ and $\left(\rho_{w}\right)=$ $1000 \mathrm{Kg} / \mathrm{m}^{3}$.

From equation 1 ; the mass flow rate for the cold water is given by;

$\dot{m}_{c}=\dot{Q}_{C} \times \rho_{w}=0.00030 \times 1000=0.3 \mathrm{~kg} / \mathrm{s}$

c) For Hot Fluid Tank:

Height of the tank is $0.380 \mathrm{~m}$, the diameter of the tank is $0.383 \mathrm{~m}$ and diameter of the pipe is $0.013 \mathrm{~m}$

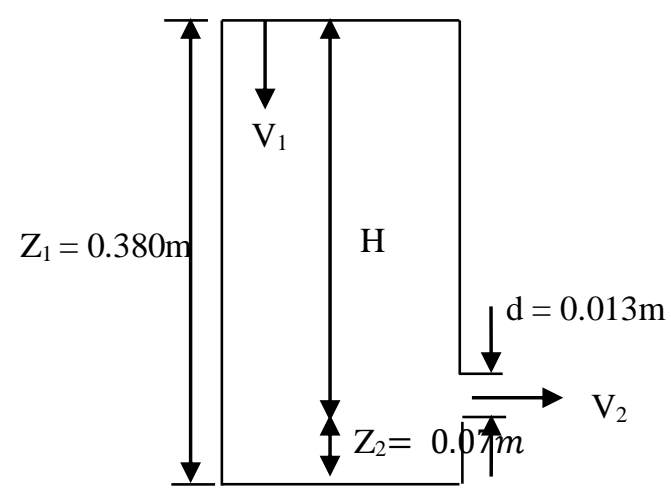

Fig. 4. Hot fluid tank
$V_{h}=C_{v} \sqrt{2 g H}$

Where the velocity coefficient of water $C_{v}=0.97$

$=0.97 \times \sqrt{2 \times 9.81 \times 0.31}=2.4 \mathrm{~m} / \mathrm{s}$

The liquid volume flow rate $\left(\dot{Q_{h}}\right)=C_{c} \frac{\pi d^{2}}{4} V_{h}$

Where the contraction coefficient for well-rounded aperture $\left(C_{c}\right)=0.97$

$$
\left(\dot{Q_{h}}\right)=0.97 \times \frac{\pi(0.013)^{2}}{4} \times 2.4=0.00031 \mathrm{~m}^{3} / \mathrm{s}
$$

This implies that; $\left(\dot{Q_{h}}\right)=0.00031 \mathrm{~m}^{3} / \mathrm{s}$ and $\left(\rho_{w}\right)=$ $1000 \mathrm{Kg} / \mathrm{m}^{3}$.

From equation 1; the mass flow rate of the hot water tank is given by;

$$
\dot{m}_{h}=\dot{Q}_{h} \times \rho_{w}=0.00031 \times 1000=0.31 \mathrm{~kg} / \mathrm{s}
$$

\section{d) Heat Balance of Shell and Tube Heat Exchanger}

Assuming no heat loss, then the heat duty [18] is given in Equation (4);

$Q_{h}=Q_{c}=\dot{m}_{h} C_{P}\left(T_{h, i}-T_{h, o}\right)=\dot{m}_{c} C_{P}\left(T_{c, 0}-T_{c, i}\right)$

$\left(T_{c, i}\right)=25^{0}, \quad\left(T_{c, 0}\right)=?, \quad\left(m_{c}\right)=0.3 \mathrm{~kg} / \mathrm{s}, \quad\left(m_{h}\right)=$ $0.31 \mathrm{~kg} / \mathrm{s},\left(C_{P}\right)=4.186 \times 10^{3} \mathrm{~J} / \mathrm{kg}^{\circ} \mathrm{C},\left(T_{h, i}\right)=100^{\circ} \mathrm{C}$, and $\left(T_{h, o}\right)=$ fixed at a minimum of $74{ }^{\circ} \mathrm{C}$.

Therefore;

$0.3 \times 4.186 \times 10^{3}\left(T_{c, 0}-25\right)=0.31 \times 4.186 \times$ $10^{3}(100-74)$

$1255.8\left(T_{c, 0}-25\right)=33739.2$

$t_{c, 0}-25=27$

$t_{c, 0}=27+25=52^{\circ} \mathrm{C}$

Then, the Heat Duty for Hot fluid is given by;

$Q_{h}=\dot{m}_{h} C_{P}\left(T_{h, i}-T_{h, o}\right)$

$Q_{h}=0.31 \times 4.186 \times 10^{3}(100-74)=33739.2 \mathrm{~W}=$ $34 \mathrm{~kW}$

Also, the Heat Duty for Cold fluid is given by;

$$
Q_{c}=\dot{m}_{c} C_{P}\left(T_{c, 0}-T_{c, i}\right)
$$

$Q_{c}=0.3 \times 4.186 \times 10^{3}(52-25)=33906.6 \mathrm{~W}=$ $34 k W$

e) Capacity Ratio[19]

$$
\begin{aligned}
& R=\frac{T_{h, i}-T_{h, o}}{T_{c, 0}-T_{c, i}} \\
& R=\frac{T_{h, i}-T_{h, o}}{T_{c, 0}-T_{c, i}} \frac{100-74}{52-25}=\frac{26}{27}=0.96
\end{aligned}
$$

\section{f) Effectiveness [19]}

$S=\frac{T_{c, 0}-T_{c, i}}{T_{h, i}-T_{c, i}}$ $0.013 m$

$$
V_{h}=V_{2}
$$$$
H=Z_{1}-Z_{2}=0.38-0.07=0.31 \mathrm{~m}
$$

Liquid outlet Velocity for the hot fluid is given by
$S=\frac{T_{c, 0}-T_{c, i}}{T_{h, i}-T_{c, i}}=\frac{52-25}{100-25}=\frac{27}{75.0}=0.36$ 
g) Log mean Temperature Difference (LMTD) [20]

$L M T D=\frac{\left(T_{h i-} T_{c o}\right)-\left(T_{h o-} T_{c i}\right)}{\ln \frac{\left(T_{h i-} T_{c o}\right)}{\left(T_{h o-} T_{c i}\right)}}$

$L M T D=\frac{(100-52)-(74-25)}{\ln \frac{(100-52)}{(74-25)}}=\frac{(48-49)}{\ln \frac{(48)}{(49)}}=\frac{-1}{\ln 0.98}$

$=\frac{-1}{-0.02}=50^{\circ} \mathrm{C}$

h) Correction Factor [20]

$(F)=\frac{\left(R^{2}+1\right)^{\frac{1}{2}} \times \operatorname{In}\left(\frac{(1-S)}{1-R S}\right)}{(R-1) \times \operatorname{In}\left(\frac{2-S\left(R+1-\left(R^{2}+1\right)^{\frac{1}{2}}\right.}{2-S\left(R+1+\left(R^{2}+1\right)^{\frac{1}{2}}\right.}\right)}$

$(F)=\frac{\left(0.96^{2}+1\right)^{\frac{1}{2}} \times \operatorname{In}\left(\frac{(1-0.36)}{1-0.36 \times 0.96}\right)}{(0.96-1) \times \operatorname{In}\left(\frac{2-0.36\left(0.96+1-\left(0.96^{2}+1\right)^{\frac{1}{2}}\right.}{2-0.36\left(0.96+1+\left(0.96^{2}+1\right)^{\frac{1}{2}}\right.}\right)}=\frac{-0.031}{-0.033}=$

$0.94=94 \%$

i) Corrected (LMTD)

Corrected $L M T D=F \times L M T D$

Corrected $(L M T D)=0.94 \times 50=47^{\circ} \mathrm{C}$

j) Overall Heat Transfer Coefficient (For Hot fluid) [20]

$$
U_{\text {Design }}=\frac{Q_{h}}{A \times \text { Corrected LMTD }}
$$

Where; $A=\frac{2}{S}-1-R=\frac{2}{0.36}-1-0.96=3.60 m^{2}, Q_{h}=$ $34 \mathrm{~kW}$, and Corrected LMTD $=47^{\circ} \mathrm{C}$

$\left(U_{\text {Design }}\right)=\frac{Q_{h}}{A \times \text { Corrected LMTD }}=\frac{34}{3.6 \times 47}=0.201 \mathrm{~kW} / \mathrm{m}^{2}{ }^{0} \mathrm{C}$ $=201 \mathrm{~W} / \mathrm{m}^{20} \mathrm{C}$

\section{k) Shell Side Heat Transfer Coefficient [2]}

$$
h_{O}=0.023\left(R_{e}\right)^{0.8}\left(P_{r}\right)^{0.3} \frac{\mathrm{K}}{d_{h}}
$$

The properties of saturated water at mean temperature of $87^{\circ} \mathrm{C}$ are $\rho=967 \mathrm{~kg} / \mathrm{m}^{3}, C_{P}=4203 \mathrm{KJ} / \mathrm{kgK}, K=$ $0.674 \mathrm{~W} / \mathrm{m} . K=, \mu_{s}=0.0003258 \mathrm{~N} / \mathrm{m}^{2} . S, P_{r}=2.032$.

From table 2 above; the hydraulic diameter for triangle pitch $D_{h}=\frac{4\left[\frac{\sqrt{3} P_{t}^{2}}{4}-\frac{\pi}{8} d_{O}{ }^{2}\right]}{\pi \frac{d_{O}}{2}}=0.7514 m$, shell side area $\quad A_{S}=\frac{\left(P_{t}-d_{O}\right) D_{S} B}{P_{t}}=0.007984 m^{2}$ and the mean velocity is $V_{s m}=\frac{m_{h}}{\rho A_{s}}=\frac{0.31}{967 \times 0.007984}=0.04 \mathrm{~m} / \mathrm{s}$

$R_{e s}=\frac{d_{h} V_{s m} \rho}{\mu_{s}}$

$R_{e s}=\frac{0,7514 \times 0.04 \times 967}{0.0003258}=89,209$

Since this value is greater than 2000 , then the flow is turbulent.

$h_{O}=0.023(89209)^{0.8}(2.032)^{0.3} \frac{0.674}{0.7514}=233.5 \mathrm{~W} /$
$m^{2} . K$

l) Tube Side Heat Transfer Coefficient [2]

$$
h_{i}=0.023\left(R_{e}\right)^{0.8}\left(P_{r}\right)^{0.4} \frac{\mathrm{K}}{\mathrm{d}_{\mathrm{i}}}
$$

The properties of saturated water at mean temperature of $38.5^{\circ} \mathrm{C}$ are $\rho=992.7 \mathrm{~kg} / \mathrm{m}^{3}, C_{P}=4178.7 \mathrm{KJ} / \mathrm{kgK}, \mathrm{K}$ $=0.629 \mathrm{~W} / \mathrm{m} . K, \mu_{t}=0.0006965 \mathrm{~N} / \mathrm{m}^{2} . S, P_{r}=4.473$, $d_{i}=0.00752$

From table 2; The tube side area $A_{t p}=\frac{\frac{\pi d_{i}{ }^{2} N_{t}}{4}}{N_{P}}=$ $0.001090 m^{2}$ and mean velocity is $V_{t m}=\frac{m_{c}}{\rho A_{t p}}=$ $\frac{0.30}{992.7 \times 0.001090}=0.28 \mathrm{~m} / \mathrm{s}$

$R_{e t}=\frac{d_{i} V_{t m} \rho}{\mu_{t}}$

$R_{e t}=\frac{0.007525 \times 0.28 \times 992.7}{0.0006965}=3,003$

Since this value is greater than 2000 , then the flow is turbulent.

$h_{i}=0.023(3003)^{0.8}(4.473)^{0.4} \frac{0.629}{0.007525}=2120 \mathrm{~W} /$

$m^{2} \cdot K$

m) Overall Heat Transfer Coefficient [14]

$U_{f}=\frac{1}{\frac{1}{h_{0}}+R_{0}+A_{0} \ln \left(\frac{r_{0}}{r_{i}}\right)+R_{i}+\frac{A_{0}}{A_{i} h_{i}}}$

Where; $\quad h_{0}=233.5 \mathrm{~W} / \mathrm{m}^{20} \mathrm{C}, \quad h_{i}=2120 \mathrm{~W} / \mathrm{m}^{20} \mathrm{C}$, $\left(R_{0}\right)=0.0002 \mathrm{~m}^{2}{ }^{0} \mathrm{C} / \mathrm{W},\left(R_{i}\right)=0.0001 \mathrm{~m}^{2}{ }^{0} \mathrm{C} / \mathrm{W}, A_{0}=$ $0.021 \mathrm{~m}^{2}, A_{i}=0.0166 \mathrm{~m}^{2}, \quad r_{0}=0.004763 \mathrm{~m}^{2}$, and $r_{i}=$ $0.003763 m^{2}$

$U_{f}=\frac{1}{\frac{1}{h_{0}}+R_{0}+A_{0} \ln \left(\frac{r_{0}}{r_{i}}\right)+R_{i}+\frac{A_{0}}{A_{i} h_{i}}}=$

$\frac{1}{\frac{1}{233.5}+0.0002+0.021 \ln \left(\frac{0.004763}{0.003763}\right)+0.0001+\frac{0.021}{0.0166 \times 2120}}$

$=98.04 \mathrm{~W} / \mathrm{m}^{2}{ }^{\circ} \mathrm{C}$

n) Shell Side Pressure Drop [2]

$\Delta P_{\text {shell }}=\frac{f G_{S}^{2} D_{S}\left(N_{B}+1\right)}{2 \rho D_{h}\left(\frac{\mu_{S}}{\mu_{t}}\right)^{0.14}}$

Where; $G_{S}=\frac{m_{h}}{A_{S}}=\frac{0.31}{0007984}=38.83 \mathrm{~kg} / \mathrm{m}^{2} \mathrm{~s}, \quad D_{S}=$ $0.254 \mathrm{~m}, N_{B}=4, \rho=967 \mathrm{~kg} / \mathrm{m}^{3}, D_{h}=0.7514 \mathrm{~m}$, $\mu_{s}=0.0003258 \mathrm{~N} \mathrm{~s} / \mathrm{m}^{2}, \quad \mu_{t}=0.0006965 \mathrm{~N} \mathrm{~s} / \mathrm{m}^{2} \quad$ and $R_{e s}=89,209$

Then, the friction factor is given by;

$f=\exp \left(0.576-0.19 \ln \left(R_{e s}\right)\right.$

$f=\exp (0.576-0.19 \ln (89,209)=0.204$ 


$$
\begin{aligned}
& \Delta P_{\text {shell }}=\frac{f G_{S}^{2} D_{S}\left(N_{B}+1\right)}{2 \rho D_{h}\left(\frac{\mu_{S}}{\mu_{t}}\right)^{0.14}}=\frac{0.204 \times 38.83^{2} \times 0.254(4+1)}{2 \times 967 \times 0.7514\left(\frac{0.0003258}{0.0006965}\right)^{0.14}} \\
& =0.2993 \mathrm{~N} / \mathrm{m}^{2}
\end{aligned}
$$

o) Tube Side Pressure Drop[2]

$\Delta P_{\text {tube }}=\frac{4 f L N_{P}}{d_{i}} \times \frac{G_{t}{ }^{2}}{2 \rho}$

Where; $L=0.7 \mathrm{~m}, d_{i}=0.007525 \mathrm{~m}, \rho=992.7 \mathrm{~kg} / \mathrm{m}^{3}$, $R_{e t}=3,003, N_{P}=2$ and $G_{t}=275.23 \mathrm{~kg} / \mathrm{m}^{2} \mathrm{~s}$

Then, the friction factor is given by [2];

$f=\left(1.58 i n R_{e t}-3.28\right)^{-2}$

$f=(1.58 \ln 3003-3.28)^{-2}=0.01312$

$\Delta P_{\text {tube }}=\frac{4 \times 0.01312 \times 0.7 \times 2}{0.007525} \times \frac{275.23^{2}}{2 \times 992.7}=373 \mathrm{~N} / \mathrm{m}^{2}$

\section{Machine Fabrication}

The machine was fabricated based on the design specification. The construction was carried out with locally sourced materials to reduce the cost of production to meet the design objective. Each of the components was designed and fabricated following the due fabrication process as shown in figure 5. This entails marking and cutting out the required shape and dimension, welding of the parts to form the components, and surface finishing improving on the aesthetic.

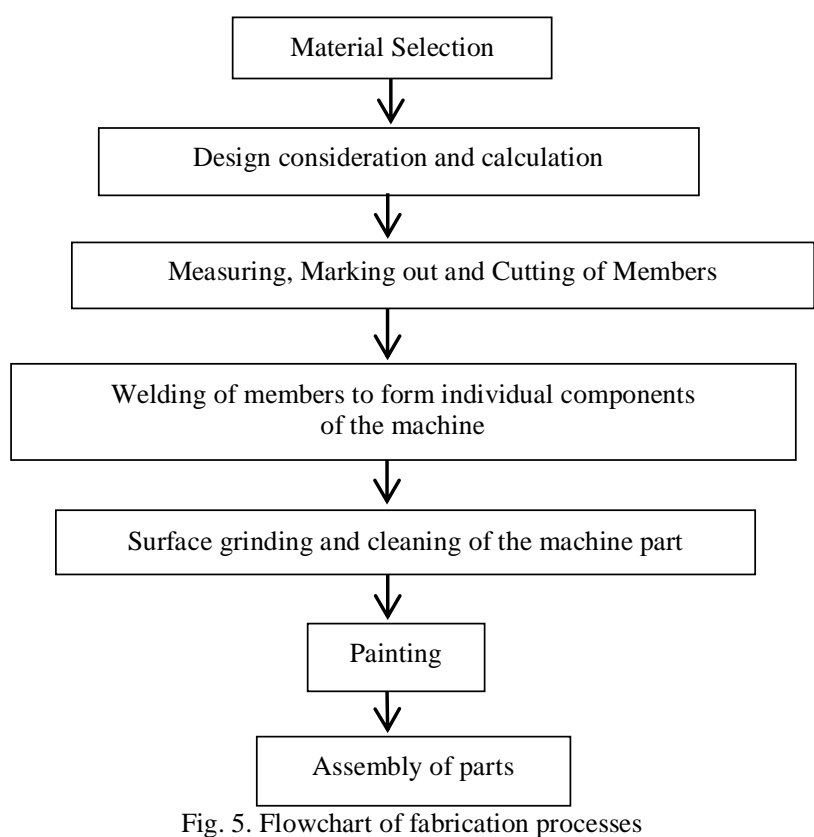

D. Working operation

1) Coldwater is poured inside the cold and hot water supply tank

2) The heater inside the hot water tank is switched on until the water starts boiling i.e when the water reached the boiling point at 100 -degree centigrade which will be indicated by the thermometer attached to the tank

3) The temperature of the cold water in the cold water supply tank is also taken i.e 25-degree centigrade

4) Both cold and hot water supply valves are open while the collector valves remain closed to allow the water flow to tubes and shell respectively

5) The cold water inside the tubes and hot water inside the shell are allowed to exchange heat for a few minutes say 10 minutes

6) The cold and hot water collector valves are open to allow the water in the tubes and shell flow to their respective collector tanks

7) The temperature of the water on both cold and hot water tanks are taken and it is expected that the water in the cold water collector will increase (above 25degree centigrade) while that of hot water decreases (below 100-degree centigrade)

The two centrifugal pumps are switched on to allow the water in the cold and hot water collector tanks flow back through the pipes to their respective water supply tanks to continue the processes over again

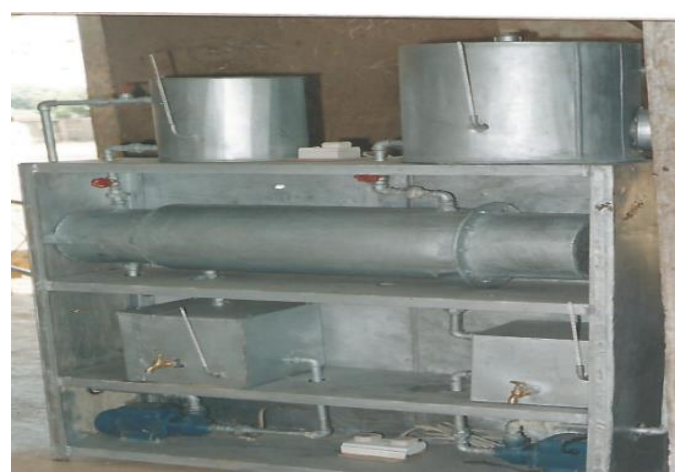

Fig. 6. Fabricated shell and tube heat exchanger

\section{RESUlt AND DisCUSSION}

\section{A. Result}

After fabrication, the system was tested and the results obtained are shown below:

TABLE III: DEGREE OF COOLING/HEATING AND EFFECTIVENESS OF THE

\begin{tabular}{|c|c|c|c|c|c|c|c|}
\hline $\begin{array}{l}\mathrm{S} / \\
\mathrm{N}\end{array}$ & $\begin{array}{l}\text { Hot } \\
\text { wat } \\
\text { er } \\
\text { Inlet } \\
\left({ }^{\circ} \mathrm{C}\right)\end{array}$ & $\begin{array}{c}\text { Hot } \\
\text { wat } \\
\text { er } \\
\text { outl } \\
\text { et } \\
\left({ }^{\circ} \boldsymbol{C}\right)\end{array}$ & $\begin{array}{c}\text { Coldwat } \\
\text { er } \\
\text { Inlet } \\
\left({ }^{\circ} \mathrm{C}\right)\end{array}$ & $\begin{array}{c}\text { Coldwat } \\
\text { er } \\
\text { outlet } \\
\left({ }^{\circ} \mathrm{C}\right)\end{array}$ & $\begin{array}{l}\text { Degre } \\
\text { e of } \\
\text { cooli } \\
\text { ng } \\
\left({ }^{\circ} \mathrm{C}\right)\end{array}$ & $\begin{array}{c}\text { Degr } \\
\text { ee of } \\
\text { heati } \\
\text { ng } \\
\left({ }^{\circ} \mathrm{C}\right)\end{array}$ & $\begin{array}{c}\text { Effectiven } \\
\text { ess of } \\
\text { Heat } \\
\text { exchanger }\end{array}$ \\
\hline 1 & $\begin{array}{c}100 . \\
0\end{array}$ & 66.9 & 25.0 & 59.5 & 33.1 & 34.5 & 0.4600 \\
\hline 2 & 95.0 & 65.2 & 25.2 & 56.5 & 29.8 & 31.3 & 0.4484 \\
\hline 3 & 90.0 & 63.0 & 25.5 & 53.6 & 27.0 & 28.1 & 0.4357 \\
\hline 4 & 85.0 & 61.0 & 25.7 & 50.6 & 24.0 & 24.9 & 0.4199 \\
\hline 5 & 80.0 & 59.3 & 26.0 & 47.6 & 20.7 & 21.6 & 0.4000 \\
\hline
\end{tabular}
HEAT EXCHANGER 


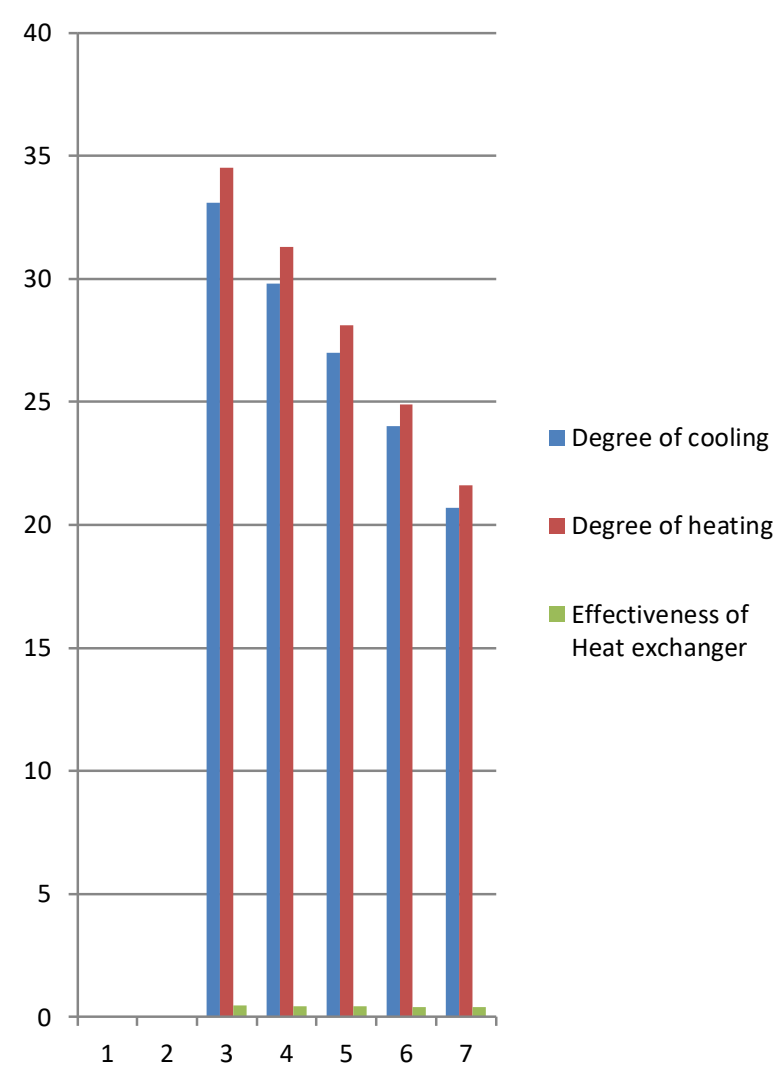

Fig 7. Graph of the degree of cooling/heating against the effectiveness of the heat exchanger

\section{B. Performance Evaluation (Test Calculation)}

From table 3 above, the average temperatures are; $T_{h, i}=$ $90.00^{\circ} \mathrm{C}, T_{h, 0}=63.1^{0} \mathrm{C}, T_{c, i}=25.48^{0} \mathrm{C}, T_{c, 0}=$ $53.56^{\circ} \mathrm{C}, \dot{m}_{c}=0.3 \mathrm{~kg} / \mathrm{s}, \dot{m}_{h}=0.31 \mathrm{~kg} / \mathrm{s}$, and $C_{P}=$ $4.186 \times 10^{3} \mathrm{~J} / \mathrm{kg}^{\circ} \mathrm{C}$.

$>$ Temperature range for hot fluid

$\Delta T=T_{h, i}-T_{h, o}=90.00-63.1=27^{0} \mathrm{C}$

Temperature range for cold fluid

$\Delta t=T_{c, o}-T_{c, i}=53.56-25.48=28^{\circ} \mathrm{C}$

$>$ Heat Duty for Hot fluid

$Q_{h}=\dot{m}_{h} C_{P} \Delta T=0.31 \times 4.186 \times 10^{3} \times 27$

$=35 \mathrm{~kW}$

$>$ Heat Duty for Cold fluid

$\left(Q_{c}\right)=\dot{m}_{c} C_{P} \Delta t=0.30 \times 4.186 \times 10^{3} \times 28$

$=35 \mathrm{~kW}$

$>$ Capacity Ratio

$R=\frac{T_{h, i}-T_{h, o}}{T_{c, 0}-T_{c, i}}=\frac{90.00-63.1}{53.56-25.48}=\frac{27}{28}=0.96$

Effectiveness

$S=\frac{T_{c, 0}-T_{c, i}}{T_{h, i}-T_{c, i}}=\frac{53.56-25.48}{90.0-25.48}=\frac{24.4}{64.52}=0.37$

$>\quad$ Log mean Temperature Difference

$L M T D=\frac{\left(T_{h i-} t_{c o}\right)-\left(T_{h o}-t_{c i}\right)}{\ln \frac{\left(T_{h i-} t_{c o}\right)}{\left(T_{h o-} t_{c i}\right)}}=$

$\frac{(90.0-53.56)-(63.1-25.48)}{\ln \frac{(90.0-53.56)}{(63.1-25.48)}}=\frac{-1.18}{-0.03}=39^{\circ} \mathrm{C}$

Correction Factor $F=\frac{\left(R^{2}+1\right)^{\frac{1}{2}} \times \operatorname{In}\left(\frac{(1-S)}{1-R S}\right)}{(R-1) \times \operatorname{In}\left(\frac{2-S\left(R+1-\left(R^{2}+1\right)^{\frac{1}{2}}\right.}{2-S\left(R+1+\left(R^{2}+1\right)^{\frac{1}{2}}\right.}\right)}=$

$\frac{\left(0.96^{2}+1\right)^{\frac{1}{2}} \times \operatorname{In}\left(\frac{(1-0.37)}{1-0.96 \times 0.37}\right)}{(0.96-1) \times \operatorname{In}\left(\frac{2-0.37\left(0.96+1-\left(0.96^{2}+1\right)^{\frac{1}{2}}\right.}{2-0.37\left(0.96+1+\left(0.96^{2}+1\right)^{\frac{1}{2}}\right.}\right)}$ $=\frac{-0.032}{-0.034}=0.94=94 \%$

Corrected LMTD

$L M T D=F \times L M T D=0.94 \times 39=37^{\circ} \mathrm{C}$

$>$ Overall Heat Transfer Coefficient

$\left(U_{\text {Cal }}\right) U_{\text {Cal }}=\frac{Q_{h}}{A \times \text { Corrected LMTD }}$

Where; $\quad A=\frac{2}{S}-1-R=\frac{2}{0.37}-1-0.96=$ $3.45 \mathrm{~m}^{2}, Q_{h}=35 \mathrm{~kW}$, and Corrected LMTD $=37^{\circ} \mathrm{C}$

$$
U_{\text {Cal }}=\frac{Q}{A \times \text { Corrected LMTD }}=\frac{35}{3.45 \times 37}
$$

$=0.274 \mathrm{~kW} / \mathrm{m}^{20} \mathrm{C}=274 \mathrm{~W} / \mathrm{m}^{2}{ }^{\circ} \mathrm{C}$

\section{Fouling Factor}

$F=\frac{1}{U_{\text {Design }}}-\frac{1}{U_{\text {Cal }}}=\frac{1}{201}-\frac{1}{274}$

$=0.00498-0.00365=0.00133 \mathrm{~m}^{2}{ }^{\circ} \mathrm{C} / W$

TABLE IV: COMPARISON OF TEST DATA WITH DESIGN DATA

\begin{tabular}{|c|c|c|c|c|c|}
\hline PARAMETER & Symbol & Units & $\begin{array}{l}\text { Test } \\
\text { Data }\end{array}$ & $\begin{array}{c}\text { Design } \\
\text { Data }\end{array}$ & $\begin{array}{c}\text { Deviation } \\
(\%)\end{array}$ \\
\hline $\begin{array}{l}\text { Temperature } \\
\text { range for hot } \\
\text { fluid }\end{array}$ & $\Delta T$ & ${ }^{\circ} \mathrm{C}$ & 27.000 & 26.000 & 3.70 \\
\hline $\begin{array}{l}\text { Temperature } \\
\text { range for cold } \\
\text { fluid }\end{array}$ & $\Delta t$ & ${ }^{\circ} \mathrm{C}$ & 28.000 & 27.000 & 3.57 \\
\hline $\begin{array}{l}\text { Heat duty for } \\
\text { hot fluid }\end{array}$ & $Q h$ & $k W$ & 32.000 & 34.000 & 2.89 \\
\hline $\begin{array}{l}\text { Heat duty for } \\
\text { cold fluid }\end{array}$ & $Q c$ & $k W$ & 35.000 & 34.000 & 2.89 \\
\hline Capacity ratio & $\mathrm{R}$ & - & 0.960 & 0.960 & 0.00 \\
\hline Effectiveness & $\mathrm{S}$ & - & 0.370 & 0.360 & 2.70 \\
\hline $\begin{array}{c}\text { Corrected log } \\
\text { mean } \\
\text { temperature } \\
\text { difference }\end{array}$ & LMTD & ${ }^{\circ} \mathrm{C}$ & 37.000 & 47.000 & 21.28 \\
\hline $\begin{array}{c}\text { Overall Heat } \\
\text { transfer } \\
\text { coefficient }\end{array}$ & $\mathrm{U}$ & $\begin{array}{l}W \\
/ m^{20} \mathrm{C}\end{array}$ & 274.000 & 201.000 & 26.64 \\
\hline Fouling Factor & $\mathrm{F}$ & $\begin{array}{l}m^{20} C \\
/ W\end{array}$ & 0.004 & 0.005 & 20.00 \\
\hline $\begin{array}{l}\text { Temperature } \\
\text { range for hot } \\
\text { fluid }\end{array}$ & $\Delta T$ & ${ }^{\circ} \mathrm{C}$ & 27.000 & 26.000 & 3.70 \\
\hline $\begin{array}{l}\text { Temperature } \\
\text { range for cold } \\
\text { fluid }\end{array}$ & $\Delta t$ & ${ }^{\circ} \mathrm{C}$ & 28.000 & 27.000 & 3.57 \\
\hline $\begin{array}{l}\text { Heat duty for } \\
\text { hot fluid }\end{array}$ & $Q h$ & $k W$ & 32.000 & 34.000 & 2.89 \\
\hline $\begin{array}{l}\text { Heat duty for } \\
\text { cold fluid }\end{array}$ & $Q c$ & $k W$ & 35.000 & 34.000 & 2.89 \\
\hline Capacity ratio & $\mathrm{R}$ & - & 0.960 & 0.960 & 0.00 \\
\hline Effectiveness & $\mathrm{S}$ & - & 0.370 & 0.360 & 2.70 \\
\hline $\begin{array}{c}\text { Corrected log } \\
\text { mean } \\
\text { temperature } \\
\text { difference }\end{array}$ & LMTD & ${ }^{\circ} \mathrm{C}$ & 37.000 & 47.000 & 21.28 \\
\hline $\begin{array}{c}\text { Overall Heat } \\
\text { transfer } \\
\text { coefficient }\end{array}$ & $\mathrm{U}$ & $\begin{array}{l}W \\
/ m^{2}{ }^{0} C\end{array}$ & 274.000 & 201.000 & 26.64 \\
\hline Fouling Factor & $\mathrm{F}$ & $\begin{array}{l}m^{20} C \\
/ W\end{array}$ & 0.004 & 0.005 & \\
\hline
\end{tabular}




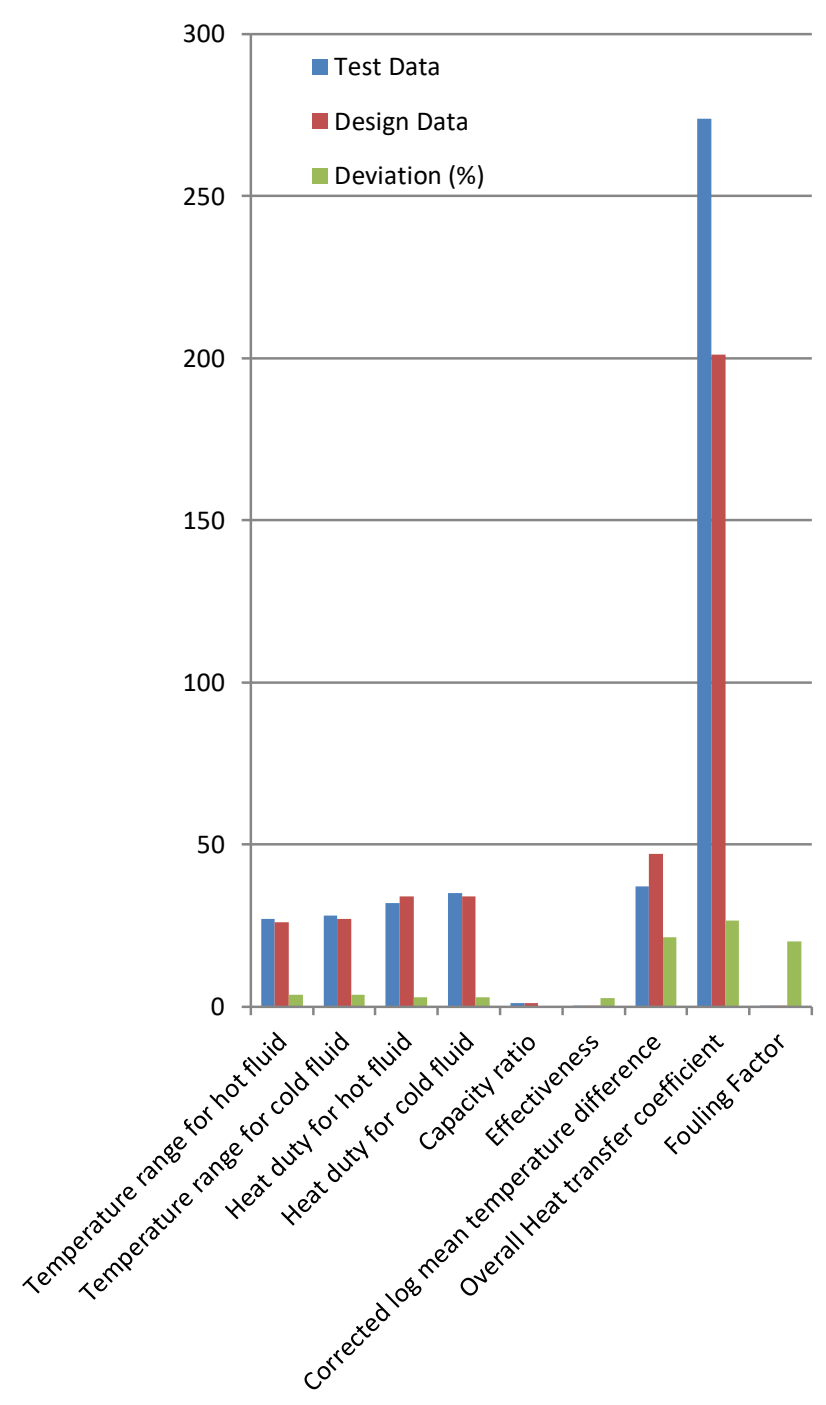

Fig 8. Graph of test data against design data parameters of the heat exchanger

\section{Discussion}

The results for the heat exchanger as shown in table III above were obtained by carrying out a test on the heat exchanger following the working operational procedures as shown in table III above. The test results were evaluated using the various inlets and outlet temperatures to determine the performance of the heat exchanger as shown in table IV. Table III shows the computation of the degree of cooling, degree of heat, and effectiveness of the heat exchanger while tables 4 shows the percentage performance of the various indicators concerning the design values.

From table III; the first test shows that the cold water inlet temperature was at $25^{\circ} \mathrm{C}$ and the hot water at $100^{\circ} \mathrm{C}$ attains the boiling point after two hours. Then the fluids were allowed to exchange heat within ten minutes, the final temperature for the hot water was noted to decrease from $100^{\circ} \mathrm{C}$ down to $66.9^{\circ} \mathrm{C}$ and that of the cold water increased from $25^{\circ} \mathrm{C}$ to $59.5^{\circ} \mathrm{C}$. For the second test carried out, the cold water inlet temperature at $25.2^{\circ} \mathrm{C}$ and $95^{\circ} \mathrm{C}$ of hot water, the final temperature of the cold water increased from an initial temperature of $25.2^{\circ} \mathrm{C}$ to $56.5^{\circ} \mathrm{C}$ while that of hot water decreased to $65.2^{\circ} \mathrm{C}$ within eight and half minutes. For the third test conducted, the hot water decreased from $90^{\circ} \mathrm{C}$ to $63.0^{\circ} \mathrm{C}$ while that of the cold water increased from $25.5^{\circ} \mathrm{C}$ to $53.6^{\circ} \mathrm{C}$ within seven and a half minutes. For the fourth test conducted, the hot water decreased from $85^{\circ} \mathrm{C}$ to $61.0^{\circ} \mathrm{C}$ while that of the cold water increased from $25.7^{\circ} \mathrm{C}$ to $50.6^{\circ} \mathrm{C}$ within six and a half minutes. And the last test conducted shows that, the hot water decreased from $80^{\circ} \mathrm{C}$ to $59.3^{\circ} \mathrm{C}$ while that of the cold water increased from $26.0^{\circ} \mathrm{C}$ to $47.6^{\circ} \mathrm{C}$ within six minutes. From the five tests carried out on the heat exchanger, the degree of cooling fluctuates between $33.1^{\circ} \mathrm{C}$ to $20.7^{\circ} \mathrm{C}$ while the degree of heating fluctuates from $34.5^{\circ} \mathrm{C}$ to $21.6^{\circ} \mathrm{C}$. Fluctuations could be linked to so many factors ranging from the effect of the lagging material, ambient temperature, etc.

From table IV above; the temperature range of the cold fluid is $28^{\circ} \mathrm{C}$ of the test value with a deviation from the design value of $3.57 \%$ which could be due to the increased fouling in the tubes (cold stream) since a higher pressure drop is noticed. The heat duty of the hot and cold fluid represents $35 \mathrm{~kW}$ of the test value with a deviation from the design value of $2.89 \%$ for which the differences could be a result of specific heat capacity variation with temperature or heat loss due to radiation from the hot shell side. The capacity ratio represents 0.96 of the test and design value without any deviation, the effectiveness represents 0.37 of the test value with a deviation of $2.70 \%$ and corrected LMTD represent $37^{\circ} \mathrm{C}$ of the test value with a deviation of $21.28 \%$ performance from the design values which are likely due to the specific heat capacity deviation and heat losses across the heating elements. The overall heat transfer coefficient of the heat exchanger is $274 \mathrm{~W} / \mathrm{m}^{2}{ }^{0} \mathrm{C}$ of the test value with a deviation of $26.64 \%$ from the design value which can be attributed to changes in the heat transfer surface, temperature difference, physiochemical properties of the fluids, the geometry of the heat exchanger and velocity of the flowing fluids. The fouling factor is 0.004 $\mathrm{W} / \mathrm{m}^{2}{ }^{0} \mathrm{C}$ of the test value with a deviation of $20 \%$ from the design value which is due to the uneven velocity profile, back-flows, and eddies generated on the shell side of a segmentally -baffled of the heat exchanger.

\section{CONCLUSION AND RECOMMENDATION}

\section{A. Conclusion}

Heat exchangers are classified as equipment capable of transferring heat from one medium to another. Heat exchanger design is characterized by specifying a design heat transfer area, pressure drops, and checking if the assumed design conforms with the requirement or not. To ensure this, the methodology was developed to carry out the design calculation to ensure the optimum performance of the heat exchanger for practical application.

The shell and tube heat exchanger was designed, fabricated, and evaluated to determine the performance of the heat exchanger focusing on the parameters such as heat duty, capacity ratio, effectiveness, overall heat transfer coefficient, and fouling factor. The test results were compared with the design data using the performance parameters above and the results show that the temperature range, heat duty, capacity ratio, and effectiveness were reasonably close while the corrected log mean temperature difference, overall transfer coefficient, and fouling factor 
were not.

The small deviation in the temperature range could be as a result of increased fouling in the tubes since higher pressure exists at tube side while that of shell side is normal; the little differences noticed in the heat duty could be as a result of specific heat capacity deviation with temperature and heat loss due to radiation from the shell side of the heat exchanger; there was a decreased in heat transfer coefficient due to increased fouling which minimized the active area of heat transfer, overall transfer coefficient and fouling factor. The deviation noticed on the corrected log mean temperature difference is likely due to the specific heat capacity deviation and heat losses across the heating elements. For the overall heat transfer coefficient, the deviation can be attributed to changes in the heat transfer surface, temperature difference, physiochemical properties of the fluids, geometry of the heat exchanger and velocity of the flowing fluids while the deviation in the fouling factor could be due to uneven velocity profile, back-flows, and eddies generated on the shell side of a segmentally -baffled of the heat exchanger. It is clear that the temperature gradient, increase in fouling, and heat loss affects the performance of the heat exchanger.

The overall system performance depends greatly on the temperature difference across the stream which is a function of the heat transfer area and material. In general, there were some deviations on design parameters compared with test values, but the overall performance of the heat exchanger was quite impressive and satisfactorily works under standard conditions.

The shell and tube heat exchangers require regular cleaning and maintenance to operate at high efficiency. Thus, a rigorous overhaul schedule aimed at countering the effects of fouling that result from solids (like foreign particles or precipitates) accumulating on the heat exchanger surfaces inhibiting heat transfer, low wall shear stress, and restricted fluid flow. Chemical additives can also be added on the heat exchanger to prevent the precipitation of particles which is usually considered as the most costeffective way of preventing fouling.

The shell and tube heat exchanger performance can deteriorate with time and it is important to assess the performance of the system periodically to maintain them at a high-efficiency level.

The results obtained proved that the heat exchanger is effective, reliable and provides a good technical approach to evaluate the thermal performance of the heat exchanger and will be useful in conducting heat and mass transfer practical in thermodynamics laboratory.

\section{B. Recommendation}

1) More tests are recommended using different fluids apart from water

2) Different steel and lagging materials should be used in place of mild steel and cotton wool

3) Different range of temperatures adopted

4) The heat exchanger should be constructed and tested under various flow conditions using the insulations of aluminum foil, tape, foam, paper, etc.

\section{APPENDIX}

\section{APPENDIX A: Orthographic and Assembly view}

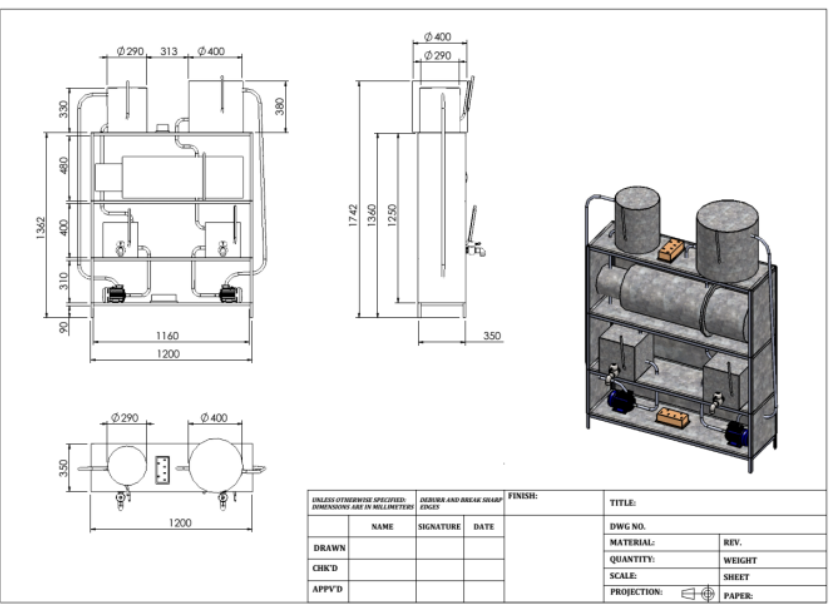

\section{APPENDIX B: Exploded view}

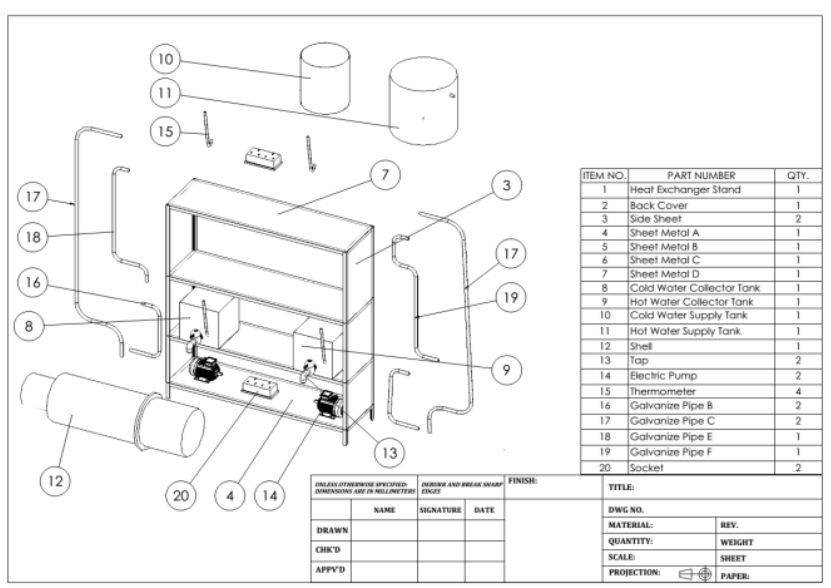

\section{APPENDIX C: Orthographic and Isometric view of the stand}

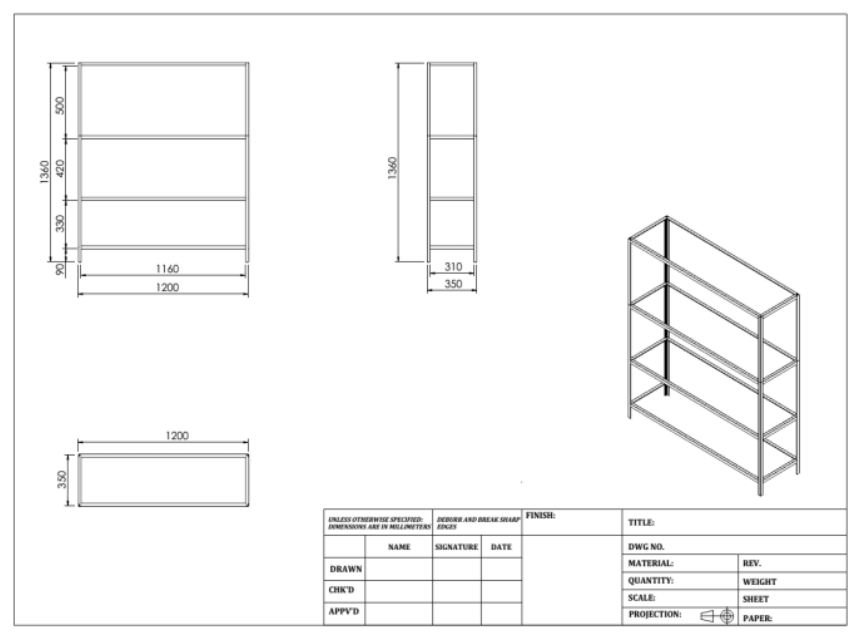

APPENDIX D: Sectional view of the water supply tank 


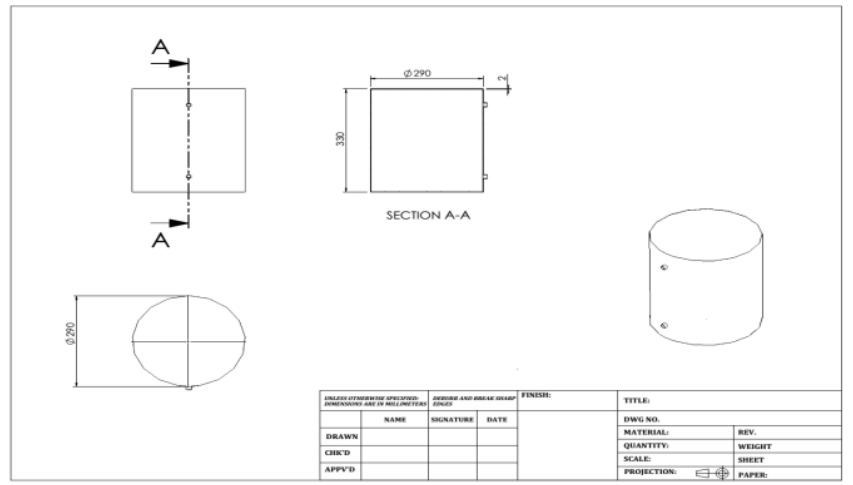

\section{NOMENCLATURE}

\begin{tabular}{llc}
$A$ & Heat transfer area & $\mathrm{m}^{2}$ \\
$C_{P}$ & Specific heat capacity of water & $\mathrm{kJ} / \mathrm{kg}^{\circ} \mathrm{C}$ \\
$F$ & Fouling factor & $\mathrm{m}^{2}{ }^{\circ} \mathrm{C} / \mathrm{kW}$ \\
$h_{i}$ & Tube heat transfer coefficient & $\mathrm{W} / \mathrm{m}^{2 \circ} \mathrm{C}$ \\
$h_{0}$ & Shell heat transfer coefficient & $\mathrm{W} / \mathrm{m}^{2 \circ} \mathrm{C}$ \\
$U$ & Overall heat transfer coefficient & $\mathrm{W} / \mathrm{m}^{2 \circ} \mathrm{C}$ \\
$U_{C a l}$ & Overall heat transfer coefficient of test data & $\mathrm{W} / \mathrm{m}^{2 \circ} \mathrm{C}$ \\
$U_{\text {Design }}$ & Overall heat transfer coefficient of design data $\mathrm{W} / \mathrm{m}^{2 \circ} \mathrm{C}$ \\
$m$ & Mass flow Rate & $\mathrm{kg} / \mathrm{s}$ \\
$Q$ & Heat duty of the fluid & $\mathrm{kW}$ \\
$R$ & Capacity ratio & - \\
$S$ & Effectiveness & - \\
$T_{h i}$ & Inlet temperature of hot fluid & ${ }^{\circ} \mathrm{C}$ \\
$T_{h o}$ & Outlet temperature of hot fluid & ${ }^{\circ} \mathrm{C}$ \\
$T_{c i}$ & Inlet temperature of cold fluid & ${ }^{\circ} \mathrm{C}$ \\
$T_{c o}$ & Outlet temperature of cold fluid & ${ }^{\circ} \mathrm{C}$ \\
$\Delta_{T}$ & Temperature range of hot fluid & ${ }^{\circ} \mathrm{C}$ \\
$\Delta_{t}$ & Temperature range of cold fluid & ${ }^{\circ} \mathrm{C}$ \\
$L M T D$ & Log mean temperature difference & ${ }^{\circ} \mathrm{C}$ \\
$L M T D_{C}$ & Corrected log mean temperature & \\
\multicolumn{4}{l}{ difference } & ${ }^{\circ} \mathrm{C}$ \\
$\Delta_{P}$ & Pressure drop & $\mathrm{N} / \mathrm{m}^{2}$ \\
$R_{e}$ & Reynolds number & - \\
$F$ & Correction factor & - \\
$f$ & Friction factor & -
\end{tabular}

\section{ACKNOWLEDGEMENTS}

We want to acknowledge EJERS' reviewer and Chief Editor for their excellent contribution during the reviewing processes. Many thanks go to all Academic staff of Mechanical Engineering and Agricultural/Bio Environmental Technology Department Federal Polytechnic Ede, Osun state for their support throughout the project work.

\section{REFERENCES}

[1] V.V.P. Dubey, R.R. Verma, P.S. Verma, and A.K. Srivastava, "Performance Analysis of Shell \& Tube Type Heat Exchanger under the Effect of Varied Operating Conditions", IOSR Journal of Mechanical and Civil Engineering (IOSR-JMCE), e-ISSN: 22781684, p-ISSN: 2320-334X, Volume 11, Issue 3 Ver. VI. pp. 08-17, 2014

[2] R. K. Sinnott, M.C John, and F. R. John, "Colson and Richardson's Chemical Engineering Design", Butterworth-Heinemann, vol. 6, 4th ed., 2003.

[3] A.O. Adelaja, S.J. Ojolo, and M.G. Sobamowo, "Computer-Aided Analysis of Thermal and Mechanical Design of Shell and Tube Heat Exchangers", Advanced Materials, Trans Tech Publications Switzerland, Vol. 367. pp.731-737, 2012.

[4] G. Don and P. Robert, "Perry's Chemical Engineers Handbook", McGraw-Hill Professional, 8th ed, 2007.

[5] R. K. Shah, and D. P. Seculik, "Fundamental Exchanger Design". Wiley: New York, 2003.

[6] A.F. Jozaei, A. Baheri, M.K., Hafshejani, A. Arad, WASJ18, 7, 2012
[7] B. Parikshit, K.R. Spandana, V. Krishna, T.R. Seetharam, K.N. Seetharamu, IJHMT84 (2015)

[8] J. Guziałowska, G. Ligus, R. Ulbrich, Proceedings of 5th International Conference on Transport phenomena in Multiphase Systems (Bialystok, 2008)

[9] T.H. Chang, Ch. Lee, H. Lee, K.S. Lee, J. Therm. Sci. 24, 4, 2015

[10] J.E. Hesselgreaves. "An Approach to fouling Allowance in the Design of Compact Heat Exchangers". Journal of Applied Thermal Engineering, 22. pp. 700-720, 2002

[11] D. B. Nitesh and M. Basavaraj, "Experimental Analysis and Performance Characteristic of Heat Transfer in Shell and Twisted Tube Heat Exchanger", Inter. journal Research of Engineering and Technology (IRJET). pp. 1142, 2015

[12] H. Hari, R. Ravindra, and Sreehari, "Thermal Analysis of Shell and Tube Heat Exchanger Using C and Ansys", Int. J. of Computer Trends and Technology (IJCTT) - volume 4, 2013.

[13] HK Huichuan International Petroleum Equipment Co., Limited: https://www.hcpetroleum.hk/product-detail/heat-exchanger

[14] K.J. Bell, "Heat exchanger design for the process industries", transactions of the ASME, Trans. ASME J. Heat Transfer, 126 (6) pp. 877-885, 2004.

[15] B.I. Master, K.S. Chunangad, A.J. Boxma, D., Kral, and P. Stehlík, "Most frequently used heat exchangers from pioneering research to worldwide applications", Heat Transfer Eng. 27 (6). pp. 4- 11, 2006.

[16] B. Durgesh and M.J. Priyanka, "Shell and Tube Heat Exchanger Performance Analysis", IJSR, ISSN: 23197064, 2011.

[17] M.L Kevin., "An experiment to increase heat exchanger performance", It may be feasible to consider enhanced heat transfer through the use of finned tubes, inserts, twisted tubes, or modified baffles, 1998.

[18] D.Q. Kern, "Process Heat Transfer", $7^{\text {th }}$ Edition, McGraw-Hill, Inc. New York, 1965.

[19] R.K. Rajput, "Heat and Mass Transfer" 3rd Edition, S.Chand and Company Limited, Ram Nagar, New Delhi. pp. 569-648, 2006.

[20] R.W. Serth, "Process Heat Transfer, Principles and Applications", Elsevier Science \& Technology Books Publisher, 2007.

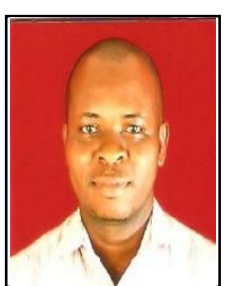

Abdulmumuni Bashiru obtained a National and Higher National Diploma in Mechanical Engineering from Kaduna Polytechnic Kaduna State, Nigeria, and B.Eng in Mechanical Engineering from Kwara State University Malete, Kwara State, Nigeria. He is currently a Senior Instructor at the Mechanical Engineering Technology Department, Federal Polytechnic Ede, Osun State, Nigeria having six (6) years of teaching experience. His research interest is in the Thermo fluid, Renewable Energy and Solar Energy. E-mail: masburk1245@gmail.com.

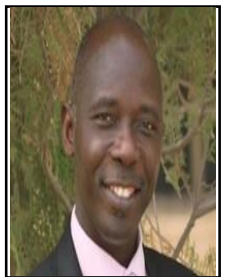

Adedeji Mathew Ayoade obtained B.Sc. in Agric Engineering (Farm Power/Machinery) from the Obafemi Awolowo University, Ile-Ife, Osun-State, Nigeria, and M.Sc. Agricultural Engineering (Farm Power/Machinery) from Obafemi Awolowo University, Ile-Ife, Osun-State, Nigeria. $\mathrm{He}$ is currently a Principal Lecturer at Agricultural and Bio-Environmental Engineering Technology Department, Federal Polytechnic Ede; Osun State, Nigeria and has twenty-three (23) years of teaching experience. His research interest is in the Development of Postharvest and Processing Machines, Agricultural Power and Machinery Management and Maintenance, Farm Electrification, and Agricultural Mechanization, Small Scale Solar Power Machines, research on renewable energy. E-mail maadedeji@fptb,edu.ng.

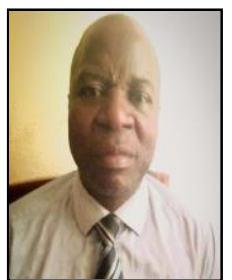

Ologunye Opeyemi Buhari obtained B.Eng in Metallurgy and Material Engineering from the Federal University of Technology Akure Ondo State Nigeria, and M.Sc in Mechanical Engineering from the University of Ibadan Oyo State, Nigeria. He is currently a Lecturer at the Mechanical Engineering Technology Department, Federal Polytechnic Ede; Osun State, Nigeria and has Eight (8) years of teaching experience. His research interest is in Corrosion Engineering, Energy, Thermodynamics, and Material Engineering. E-mail: opeologunye@yahoo.com 


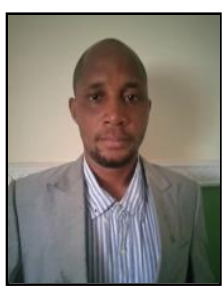

Azeez Rasheed Olatunde obtained B.Eng in Mechanical Engineering from the Federal University of Technology, Minna, Niger State, Nigeria, and M.Sc in Mechanical Design \& Production Engineering from the University of Lagos, Nigeria. He is currently a Lecturer and Head of Department at Mechanical Engineering Technology Department, Federal Polytechnic Ede; Osun State, Nigeria and has Nine (9) years teaching experience. His research interest is in Metal Forming \& Manufacturing Process, Mechatronics \& Autotronics Technology, Renewable an Sustainable Energy Utilization, Mechanical System Design and Optimization, and Industrial Waste Management \& Biogas Technology. Email: engr.roazeez@gmail.com.

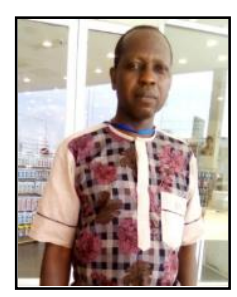

Fanifosi Johnson Olaniyi obtained National and Higher National Diploma in Mechanical Engineering from Osun State College Of Technology, Esa-Oke, Osun State, Nigeria, and B.Eng in Mechanical Engineering from Kwara State University Malete, Kwara State, Nigeria. He is currently a Technologis at the Mechanical Engineering Technology Department, Federal Polytechnic Ede, Osun State, Nigeria having six (6) years of practical teaching experience. His research interest is in the Thermo fluid, Renewable Energy and Solar Energy. E-mail: niyifanifosi@yahoo.com 